\title{
Love in the time of coronavirus
}

\author{
In the defining crisis of our times, one thing underpins actions, decisions, politics, and healthcare: \\ love, writes Iona Heath
}

Iona Heath retired general practitioner

London, UK

John Berger's 1995 novel To the Wedding ${ }^{1}$ was written in response to the horrors of the AIDS epidemic, which had a much higher fatality rate than covid-19 and an age profile affecting children and younger adults disproportionately. Responding to that first decade of the AIDS epidemic, Berger wrote:

We're living on the brink, and it's hard because we've lost the habit. Once everybody, old and young, rich and poor, took it for granted. Life was painful and precarious. Chance was cruel.

The fortunate inhabitants of the richer countries of the world had lost their painful familiarity with the arbitrariness of death.

For two centuries we've believed in history as a highway which was taking us to a future such as nobody had ever known before. We thought we were exempt ... Now people live to be much older. There are anaesthetics. We've landed on the moon ... We apply reason to everything. We forgave the past its errors because they occurred in the Dark Ages. Now, suddenly we find ourselves far from any highway, perched like puffins on a cliff edge in the dark.

Back in the 80s and 90s, stigmatised minorities were perched on the cliff edge. Now, we all are, although the current virus seems particularly skilled at exploiting almost every dimension of pre-existing disadvantage, systematically picking on people who are poor, old, or imprisoned, who live in overcrowded conditions or are from black and minority ethnic communities.

Before AIDS, SARS, Ebola, and now covid-19, it was tuberculosis, the plague, cholera, typhoid, and influenza that cut swathes through the populations of the world. Perching like puffins on the cliff edge is the historically normal situation for humanity, but we had forgotten.

In richer countries, we had forgotten the power of infection to scourge humanity and had begun to assume an entitlement to health. Infection was claiming fewer and fewer lives, although it remained the leading cause of premature death in Africa. More and more people were living long enough to die of non-communicable diseases, so attention was focused on those. ${ }^{2}$ Yet, even though the increasing number of people who die of non-communicable diseases in poorer countries die earlier than those in richer countries, they are still older than most of those who die of infections.

We had somehow allowed ourselves to forget that everyone must die and that those who are lucky enough to die in old age will almost certainly die with one or more non-communicable diseases. We had begun to believe that we had a right to a long and healthy life and that any deviation from this must represent some sort of neglect. Yet everyone will die, and as Philip Larkin wrote, "What will survive of us is love."”

\section{Austerity and the attrition of love}

The idealistic creation of largely robust welfare states across Europe in the wake of the second world war can be seen as an expression of love for the whole of humanity. No one should be excluded, and no one should be endangered. But the validity of this has never been accepted across the political spectrum.

After the global financial crash of 2008, people who were ideologically opposed to social solidarity took advantage of the situation to reduce investment through the policies of austerity. In the UK and in many other countries, expenditure on almost every aspect of social solidarity was reduced: numbers of nurses and doctors fell, hospital beds disappeared, local systems of social care were eviscerated, all the emergency services were cut back. This left skeletal services with no reserve to cope with the current crisis of resurgent infection. ${ }^{4}$

Particularly relevant is the destruction of the local systems of public and environmental health that had been the traditional line of defence against outbreaks of infection, through testing, isolation, and contact tracing. ${ }^{5}$ Health service staff warned politicians repeatedly and with increasing desperation about inadequate resources and understaffing in the service and the complete unpreparedness for any new crisis.

In 2020 all the chickens have come home to roost in a fatal combination of disbelief, unpreparedness, and the simple 
carelessness that is born of arrogance and privilege. Despite repeated warnings from infectious disease experts that another global pandemic was inevitable, governments failed to recognise the risk. ${ }^{6}$ This lack of recognition was compounded by a lack of preparedness as the UK government, having let previous stockpiles become outdated, failed to secure sufficient testing material and adequate supplies of protective equipment.

Furthermore, in the current context of gung-ho optimism about the creation of an effective vaccine, we should remember that it took almost a decade to produce an effective antiviral agent for AIDS, but back in 1984 when the human immunodeficiency retrovirus was identified there was hope that a vaccine could be produced in two years. ${ }^{7}$ There is still no vaccine.

\section{Love's labour}

At this time, when we are marking our respect and gratitude to health service workers by clapping on Thursday evenings, it is important to remember that, until recently, the NHS has been repeatedly castigated for being more concerned with sickness than health. Yet, right now we are desperate for an efficient and well equipped sickness service backed up by compassionate social care.

The moment when UK Prime Minister Boris Johnson publicly acknowledged intensive care nursing as an act of love ${ }^{8}$ felt like a turning point, but it might be too much to hope that this insight will change his attitude to the love embedded in every aspect of social solidarity.

Let there be no doubt that those who risk serious illness, and even death, by continuing to undertake emotionally and physically draining work without knowing whether they or their colleagues are already infected, and without adequate protective equipment, are motivated by altruistic love for the whole of humanity. I include not only doctors and nurses and other healthcare professionals but porters, cleaners, and caterers, care home, transport, and delivery workers, shopkeepers, shelf stackers. Each one of them is enacting Franklin D Roosevelt's maxim: "Courage is not the absence of fear, but rather the assessment that something else is more important than fear." And that something else is love.

The huge commitment and courage of the first and second generation immigrants among these essential workers, and the disproportionate number of covid-19 deaths they have experienced, should make our whole country even more profoundly ashamed of the decades of racism and hostile anti-immigration attitudes that, through Windrush and perhaps even Grenfell, culminated in Brexit in January.

\section{The love of older people}

We all know that covid-19 affects and kills older people disproportionately, perhaps because of comorbidities, perhaps because of degrees of immunosenescence.

Many older people, including myself, do not want to be admitted to hospital let alone to die on a ventilator or undergo cardiopulmonary resuscitation. We do not want to undergo distressing and invasive treatment with little chance of success, and we certainly do not want to use a ventilator that could be more useful to a younger person or to subject healthcare staff to the additional viral exposure involved in intubation.

Health professionals might find it difficult to respond to these attitudes because of a pervasive fear of being accused of ageism. Perhaps the coronavirus crisis can finally broker a shared understanding that a "do not attempt resuscitation" order is not a death sentence or the devaluing of a life but an attempt to ensure dignity in dying. Who wants to die with broken ribs and a minute chance of successful resuscitation when they could die peacefully in bed holding the hand of the person they love most?

Many older people have justifiable fears of excessive interventions and don't want to survive at any price. Hospitals are overcrowded, noisy, and intensely stressful places; in this pandemic, they have also become sources of infection themselves. We urgently need to keep frail, elderly people at home as much as possible, if that is where they want to be. To make this possible, we need to develop enhanced medical and social support for families wanting to help their older relatives in this way.

\section{Love and dying}

The shocking rates of dying from and with covid-19 diminish us all, and the tragic implications for individuals and families should never be minimised. Yet, death is being allowed to displace love in many ways. Whatever we do, however much we lock down and wash our hands, people are going to die. We should not be sacrificing our humanity in the face of this infection. The ban on visiting has been unforgivably harsh.

Let us start with the presumption that no one should die of covid-19-or anything else-isolated from those they love and who love them. If we can agree to this, then we can approach the care of seriously ill people from a completely different perspective. Such a commitment is surely not beyond the wit and resources of a nation: fewer people admitted to hospital; much more support available at home and in care homes. Testing for those who want to be with their loved one and physical isolating after any risky contact. Without this, life partners, relatives, and friends are being deprived of the opportunity to say goodbye, to say the crucial things that need to be said at the end of life.

Bereavement in such circumstances becomes as traumatic as that caused by sudden death in war or disaster, and the legacy of the pandemic will include a succession of deeply troubling bereavements experienced by survivors who did not need to be excluded in the way they have been. No one should be forced to die alone, and no one should have to shoulder the burden of knowing that they left someone they loved to die alone.

Even in the face of death, there is nothing more important than love.

\section{Biography}

Iona Heath was a general practitioner for 35 years in an inner London practice and was president of the Royal College of General Practitioners from 2009 to 2012. She wrote a regular column for The BMJ until 2013.

I have read and understood BMJ policy on declaration of interests and have no relevant interests to declare.

Provenance and peer review: Not commissioned; not externally peer reviewed.

Berger J. To the Wedding. Bloomsbury Publishing, 1995.

2 World Health Organization. Non-communicable diseases country profiles 2018. 2018https: //apps.who.int/iris/handle/10665/274512.

Larkin P. An Arundel Tomb. In: Collected Poems. Marvell Press and Faber and Faber, 1988.

4 United Nations Human Rights Office of the High Commissioner. Statement on visit to the United Kingdom, by Professor Philip Alston, United Nations Special Rapporteur on extreme poverty and human rights. 16 Nov 2018. https://www.ohchr.org/en/NewsEvents/Pages/ DisplayNews. aspx? News ID $=23881$ \&Lang $\mid \mathrm{D}=\mathrm{E}$

5 Pollock AM, Roderick P. To tackle this virus, local public health teams need to take back control. Observer 2020 Apr 26. https://www.theguardian.com/world/2020/apr/26/to-tacklethis-virus-local-public-health-teams-need-to-take-back-control. 
6 Hopkins N. Revealed: UK ministers were warned last year of risks of coronavirus pandemic. Guardian 2020 Apr 24. https://www.theguardian.com/world/2020/apr/24/revealed-ukministers-were-warned-last-year-of-risks-of-coronavirus-pandemic

7 HIV.gov. A timeline of HIV and AIDS. https://www.hiv.gov/hiv-basics/overview/history/hivand-aids-timeline
8 Coronavirus: Boris Johnson thanks NHS for "saving his life" after hospital discharge. Guardian News. YouTube. 12 Apr 2020. https://www.youtube.com/watch? $\mathrm{v}=\mathrm{gNuL} 1 \mathrm{wg} T \mathrm{VYU}$

Published by the BMJ Publishing Group Limited. For permission to use (where not already granted under a licence) please go to http://group.bmj.com/group/rights-licensing/ permissions 